\title{
A Brief Analysis of the Characteristics of Feng Wang's Music Works
}

\author{
Hailan Ren \\ Anshan Normal University \\ Anshan, China
}

\begin{abstract}
As a leader in Contemporary Chinese rock music, Feng Wang plays an important role in the music field. His music breaks through the tradition and breaks the Convention, giving the rock's new color and life. This paper looks at Feng Wang's music from a wide perspective, analyzes and sorts out the characteristics and significance of Feng Wang's music works from different angles, so as to guide Chinese rock music lovers and workers to find the direction of Chinese rock music development.
\end{abstract}

Keywords—rock; music; spirit

\section{INTRODUCTION}

In contemporary society, music is not only the most important relaxation and entertainment way for most people in the process of intense work and life, but also the most important part of spiritual enjoyment. Some people just use music as a good medicine to dispel worries, while others try to pursue their music as their dream, but no matter which one they belong to, it is enough to show the importance of music. Of course, the music has been able to play such an important role in people's life, and the music style diversification is inseparable, appreciated by different people's musical style is not the same, even the same person, different environments, different age, different mood, the way he enjoy music style is different.

\section{A BRIEF INTRODUCTION TO THE DEVELOPMENT OF CHINESE ROCK MUSIC}

Rock music as a style of popular music that originated in the United States, through the fusion of the American country music rhythm, Bruce music and other musical elements gradually developed in the last century, rock music was introduced to England after the end of the 50s, has been developing rapidly in the UK, in 60 s, Britain replaced the United States as the world's rock the music center, with the Beatles as the representative of the British rock highly prosperous in $60 \mathrm{~s}$, is the history of rock music and even the history of pop music's most glorious ten years .Rock music in the development of China first appeared in Hong Kong, Macao and Taiwan, 1980, China's first rock band Kazuma Li Wang appeared in Beijing foreign language school, they mainly sang the Beatles, rolling stone's early works, then the band and other rock band aris have also set up. The early Chinese rock band most are in the form of the party, and the last century in the late 80 s, Jian Cui and his "nothing" marks the official China rock from the ground to the public, with the Chinese first rock album "rock and roll in the new long March" the birth of the new Long March, the Black Panther band's "shame" and the Tang Dynasty Band "the dream of the Tang Dynasty" were also published. During this period, in the city of our country set up rock band become a kind of fashion, at the same time, Chinese rock began to force the diversity, the famous critic Jin Zhaojun said in a statement: "the opening of the road, is the inevitable result of social development, the rock over ideology's attitude has faded the diversification, the development of music culture give the rock music living space, but if the Chinese rock also played down his own character and into pop music, it will inevitably fall into the embarrassing situation". Should rock be close to popularity? It is not only in China, but also a controversial topic in foreign countries.

\section{AN ANALYSIS OF THE FORMATION OF FENG WANG'S CREATIVE STYLE}

Feng Wang, a landmark musician in China's rock and roll, is close to popularity. At the same time, few people, like Feng Wang, do not taboo music commercially and emphasize the purity of music. All of this is not contradictory to Feng Wang. Feng Wang regards music as life. It is regarded as a sacred and inviolable part of his mind. He not only regards music production and expression as his happiest matter, but also is a part of his life. As a representative of the China rock songs, Feng Wang inherits the characteristics of rock and roll, and ingenious combination of factors of popular music, not too many people are willing to love rock and appreciate his unique style of music, so he is also very natural to China rock commercial pushed to a new height. Feng Wang's music has both freedom and commercialization of rock music. Nowadays, in the field of music becoming more and more commercialized, Feng Wang's music naturally occupies a large position.

However, For the people who don't know Feng Wang well, they think he is a social singer, is what we call the grass-roots origin, because they think Feng Wang can write so many people living on the bottom of the song, and his own experience, his lyrics are so realistic and convincing. But in real life is not this case, his music was nurtured in high school. He was admitted to Central Conservatory of Music in 1984 and began to try writing in 1988.In 1990 he 
began to follow the school orchestra performances to European countries. Feng Wang was admitted to the Central Conservatory of Music University of violin, Viola, during the University, Feng Wang official contact with rock, formed in November 1994 the band Bao Street No. 43 and served as his soul singer. After completing his undergraduate course, he entered the Central Ballet as the deputy chief violinist and resigned to become Feng Wang, the musician we now know. In 1999, Feng Wang broke out of the band signing Warner record company and found his way. "Inspirational rock" became an important theme of his music creation. Since then, the path of Feng Wang's creation and singing has become wider and wider, and has now become a household name for our rock and roll.

\section{ANALYSIS OF THE CHARACTERISTICS OF WANG FENG'S ORIGINAL WORKS}

Feng Wang has a lot of music, and many of them are well known. His works, which permeate the cultural connotation of strong humanistic temperament, directly touch people's innermost soul. So he was also called a "musical poet". Feng Wang's song is inspirational works, so the lyrics are full of energy, full of longing for a better life, he hopes his work can guide people to make the right choice of value, many of his songs seem to tell his own stories and ideas, he has a different understanding and attitude to life, he want to use his songs to encourage people to optimism, face up to life positively and explore the direction and essence of life in constant grind and reflection. The song "Beijing of Beijing" expresses the struggling and pursuit of the hard life and the beautiful life of the people at the bottom of the society. This complex emotion is well expressed in plain and sincere lyrics. Feng Wang wanted the song to resonate with the society, because he lived in Beijing, so he was more able to express his feelings. "I live here and die here". How can the lyrics not shock people? The orphan of the beautiful world is dedicated to his dead lover. There is a lyric written like this: "don't cry, dear, we must be strong and we shall smile". In a short sentence, the heart is lonely and helpless, but it is so beautiful. He expressed his infinite memories of his lover and his companionship. "Farewell to youth" is a song in the early days of Wang Feng. It is the writer's love for the death of youth. It also tells people that in the process of growing up, we must know how to take and give up and continue to go on the road of life. "Goodbye youth, good-bye, beautiful pain, goodbye youth, goodbye forever homeland", only two lyrics make the growth of helplessness and responsibility perfect interpretation. The best part of Wang Feng's music is that he can always use the shortest and simple lyrics to tell the great truth in life.

The works of Wang Feng music texture is not complicated, smooth melody concise, the chord is relatively simple. But the orchestration is very exquisite, beautiful music and show the rich sense of the picture. So it is very catchy in singing, especially easy to sing. This is also an important reason for the popularity of his works. "In the spring" one of the works of the family, the melody is very single and repeated. Although the lyrics are different, the melody is very uniform, only a slight change is made at the end of the sentence or the end of the sentence. For example, "higher flying", the melody is a single repetition, the chord is simple, the singing degree is very high. The climax is repeated several times with the gradual increase of emotion to achieve the greatest emotional explosion. The melody of Wang Feng's songs is simple and fluent, not gorgeous, but it can reflect sincerity, nature and simplicity. It seems simple to create this style of songs, but it cannot be accomplished without solid professional skills and great understanding of music.

In Feng Wang's works, rock music represents a breakthrough stifle the vitality, he asked in the song and find the answers, this is his inner emotional portrayal. In his songs, his love for rock music was revealed all the time, and he fused his life experience in rock and roll. His music is more focused on the thinking of Humanities and society, and exerts the unique and critical social and social functions of rock music to the extreme. Through the modern music of rock and roll wind, it expresses a kind of cry and a kind of confiding. It influenced many people to think about themselves and social phenomena through his music. For example, there is a lyric in his classic existence, which says, "how many people walk but are trapped in the same place; how many people live like death; how many people are loved but separated; how many of them are smiling but full of tears." In his observation, modern society has brought too many questions to everyone, and it seems that every day is busy, people have not been able to think clearly, and even become numb. In his singing, he uses the unique singing of rock and roll, such as shouting and screaming, to express his doubts about the real problems and his doubts about life. It also resonates with more people and begins to think about what the real thoughts are, what they really want and what the real meaning of life is. His work is rock style, but his song is smooth and natural. In his works, the lyrics, melody, or emotional expression, is very consistent, the rock and pop music together naturally, do not feel any abrupt, create unconventional, unique personal characteristics of rock. People who like rock music and who like mainstream pop music can find resonance in his works, so his works have a wide audience and great influence.

\section{CONCLUSION}

Feng Wang's works have strong spiritual power, and he has broad perspective. He is a keen judgment of value and has his own unique view on the reality of today's society. He constantly innovated his musical style, looked for his own spiritual path and went to practice. Although he sometimes hesitated, this indomitable spirit, also made his rock music unique style. It is not simply the insolent and screaming, but firm, responsibility and mingled with tenderness.

\section{REFERENCES}

[1] Zilin Zhong's "the rise and influence of rock music" in Chinese musicology [M] 1997.4.

[2] Anonymous "China news weekly" consumer Feng Wang [J] 2015.05.

[3] Wang Feng's "good night Beijing" self-statement [M] 2012.01. 
[4] Anonymous "Youth" taste The voice of China - Feng Wang's Loneliness 2014.08.

[5] Qin Lu's "origin of rock music and its social and cultural value" (J) music study 2003.03. 